\title{
Government Information Public Impact of Economic Growth
}

\author{
Qun Zhan \\ Wuhan University of Technology Library West China Hospital, Wuhan 430070, China \\ E-mail: zhanghfccps@126.com
}

\begin{abstract}
The era of information economy, benign information resources is scarce resources, information socio-economic activities is the most active factor. Information from the economics point of view, the transition economies in government information on the economic characteristics, economic function, pointed out that market imperfections and market information asymmetry, and the importance of open information market, namely the role of economic growth, And the unlimited demand for scarce resources of the conflict, through the allocation of resources and achieve the greatest meet the demand.
\end{abstract}

Keywords: Government Information Disclosure, Information resources, Economic growth, Asymmetry information, Game information

Mankind has entered the information society and the "digital economy" era. Technological advances greatly promoted the process of economic globalization, many countries stand to benefit. Promoting information technology as the engine of modern economic growth and social development of the modern equalizer. Information. The economy as a new economic forms, the most notable is a sign with information technology-oriented high-tech and the rapid development of the economy in a wide range of applications, has led to the sustained rapid economic development, and in an unprecedented rapid development Period of the "new economy" phenomenon. Promote the deepening of the global division of labor and economic restructuring, changing the world market and the pattern of world economic competition.

\section{Market information asymmetry need the Government Information Disclosure}

The information economy is relatively material economic terms, the essence of which is information technology, digital, the key is information structure. The incomplete market information, asymmetry and greatly hinder the development of social production. Information as a resource instead of material resources into the field of social production, greatly improving production efficiency. In economic life, asymmetric information market will shrink even some non-existent, the production efficiency is low, the market is not fair trade and unfair competition as well as producers and consumers of distortions, excess supply and inadequate supply of both the economy and a series of Consequences, resulting in inefficient allocation of economic resources and social welfare lower in political life and will have the information asymmetry Chief black-box operations, unfair administrative, civil government indifference, lack of enthusiasm for public utilities and other social problems. Therefore, asymmetric information on the socio-economic and political development are very negative. Government departments 90 percent of the flow of information and data is not not open, then the two channels of information supply is not smooth, only a small number of publicly listed company information. The serious shortage of supply of information and the prevalence of false information, and increase China's information market in the information asymmetry parties to the transaction level, resulting in the information society as a whole waste of resources and the lack of effective supply.

\subsection{The Government Information Disclosure}

Resources is the most important characteristics of availability. Information Resources in the community as a whole in the absolute proportion of the information contained in the immeasurable value of the state and society, full use of information resources, can create more material and spiritual wealth, accelerating economic development and social progress. Government Information Disclosure of information is actually the application of resources, both social and economic development, or the Government's reform and innovation, have substantial role in promoting. The so-called open government information, government agencies in accordance with legal procedures, forms, open to the public to realize their rights of information resources and allows users to query, copy, extracts, listening, watching, downloading the form of legitimate use. The public information law And its fundamental purpose is to confirm the information public in accordance with the law is the government's legal obligations, is the public's basic rights. Under the planned economy system, open information is not important. Because the major economic decisions are done by the Government, the Government Information System's main task is to lead to a higher-level services. However, in the market economy system, decision-making powers and assume the risk has been transferred to enterprises, at this time, the Government released the information to the community enhance the national economy has become operational efficiency, reduce investment risks of important social measures. 
Government information resources and opening up the transformation of government functions is one of the core elements. Market transparency goal is to ensure the construction of market information needed to make timely, accurate and fair to open, minimizing the parties to the transaction of information asymmetry of information and agents rent. To achieve this objective, must be in the form of legislation to improve the information disclosure system, the smooth flow of information supply channels, to establish a highly efficient credit information management system. Require government departments and participation of the main markets did not involve commercial confidentiality in the case of full and open their own information and related data. Through market-oriented government and the cultivation of professional organizations, unimpeded supply of market information channels and transmission mechanism.

\section{2 relatively free market in terms of market information asymmetry}

Market information asymmetry of information relative to the market in terms of the symmetry. The so-called asymmetric market information, is on the market, the two sides involved in the transaction - or both customers and shippers do not understand anything, or both sides with full information, either by both sides with the practical applications of information is not completely identical The. However, in reality, because of the different division of labor, workers formed between a huge difference in the information industry; because of congenital or acquired a number of factors, but also caused people to obtain information capacity of different transactions each other with some misleading signals, Formed a market information asymmetry of objective reality. The asymmetry of information will cause economic and social advantages of the information in the information and the inferior side. With the development of social division of labour, the degree of specialization continue to improve in every area or industry professionals and non-professionals distribution of information between the asymmetry will continue to expand, members of the society on the information gap between the more and more Large. As information resources and the dominant position of the continuous upgrading, information superiority, who will get greater competitiveness, the difference between the information monopoly of the market on the possibility of greatly increased. At the same time, the asymmetry of information triggered the product quality of uncertainty.

Generally speaking, commodity-dependent businessmen in the mobile and changes in property rights in the course of time and space for poor to earn a profit. And the time and space is the real difference between supply and demand in the information poor. Economics, with the uncertainty of market information and access to information is necessary price. Therefore, fully competitive market - it's information market competition is only a basic model, the actual market are not entirely market. In incomplete market, the information is incomplete, and also offers a very important characteristic - the asymmetry of information. Information from the asymmetry of supply and demand side of the different pursue their own interests.

\section{3 market-based information economy and social system}

The material in terms of relative economic information economy is information technology as the economic characteristics of the high-tech form, knowledge, for the production of intellectual capital into the production sector, the traditional material and economic relations of production do not innovate will seriously hamper this "new economy" Development, social system that is innovative. In contrast technological innovation, and one country, the core competitiveness of the organization for the performance of system innovation, on the development of the system to change, adapt or not effective, involving the constitutional order, cultural traditions, ideologies, customs and habits, such as the Government preferred the impact of various factors, Showing a complex system track the changes. The real change occurred through the system depends on innovation may be greater than the profits of access to institutional innovation needed to pay the cost. Technological progress in line with the requirements of the system changes in the information economy develops to a certain stage in the economic system needs innovation gradually appear. As the information economy of the factors of production information, be asked to open, and the establishment of the corresponding system. Promoting the development of the information economy, while promoting the economic development of appropriate information systems to create.

\section{Market leader, the pilot}

Market economy (also known as a free market economy or free enterprise economy) is an economic system, in which products and services under the system of production and sale of complete freedom from the free market price mechanism to guide that the market leader. Instead of the planned economy in general by the state by the guide, with the pilot. In a market economy, there is no central coordination of the system to guide its operation, but in theory, the market will be products and services through the supply of and demand for a complex interaction, and making self-organization results. Incomplete information and information asymmetry of the universality of the market operation mechanism under the changes, the traditional price mechanism to achieve Pareto efficiency of the 
effectiveness is questionable, to complete the private and marketization reform-oriented model (that is, "Washington Consensus ") Challenge.

\section{1 market failure, government failure, and the market game}

First, the monopolization of the market, asymmetric information Third, the external merchandise of four, the existence of public goods above factors are not the optimal allocation of resources, leading to inefficiency that is market failure. Under the conditions of perfect competition in the market economy in the process of running their own, rely solely on their own strength to the regulation of the community on the various existing resources are adequate and reasonable use of social resources to achieve the effective allocation of state. However, the market economy is not a panacea. Laissez-faire on the basis of market competition mechanism, is not in any field, any state are fully launched, while in other areas or occasions, even if the market mechanism can give full play, can not meet the requirements of the community as a whole with the right resources Targeted results. These problems of a market economy can not be overcome by its own inherent defect, or lack of a "market failure" (Market Failure). Regarding the failure of the Nobel Economics Prize winner Paul. Samuelson has been under such a definition, he said: "When the government policy or collective action can not be taken by means of improving the efficiency of economic operations or (leading to) the moral An acceptable income distribution, the Government will have failures. "We think the Government is the failure of the Government in order to rectify and make up for the shortcomings of market mechanisms function taken by the legislative, administrative and economic policy instruments, often in the implementation process will appear The results of various counterproductive, leading to government intervention in economic inefficiency and social welfare losses. Insufficient financial resources, imperfect system, and other factors, caused the Government should enter the field without entering into or not fully, the Government Youxinwuli, the lack of regulation means, and control mechanism not working well, difficult to effect control in place, or the play of the market The role of the field, excessive use of administrative means to manage the economy, the Government should withdraw from the field and did not withdraw from or failed to completely withdraw from, the concentration of power, unlimited liability, the result was not only unable to compensate for the deficiencies market, but Yang short restrain long hampered Normal market mechanism play a role. Excessive government intervention led to the failure.

The objectivity of asymmetric information, trading activities can be regarded as psychological contest participants in the process, thereby promoting the depth of game theory. Game information in the market is an important factor, is the key to the outcome of a game. Market information is the "axis" and "life." Information is the effective functioning of the capital market internal factors, it is market participants to conduct market transactions, leading to the decision-making based on market intermediation; market participants are information needs, is also information providers, their trading activities are not only needs the information, Will produce and display information; commodity exchange market is a place where information is exchanged and where the game market information is not complete. This is because the market there are two aspects of uncertainty: First, the market status of the external environment of uncertainty. Second, the internal market of uncertainty. Market information is not complete, whether external or internal information, for each case of a Bo Yizhe are incomplete, the market is not entirely a game competing for information; incomplete market information and asymmetries, not only Bo Yizhe direct impact on the economic interests of the difference, but will cause "bad-shares shares expulsion" of adverse selection and moral hazard, and other effects, is even more serious give rise to unfair trading in the market, reducing the efficiency of the operation of the market, caused Market shrink or even market failure. Information in the capital market requires us to the importance of funding the operation of the market, management and information system designed to give adequate attention to factors, establish and improve the mandatory information disclosure system in order to reduce the degree of market information asymmetry, the realization of fair market transactions and Orderly operation.

\section{2 maintain the market order information}

"Transition" or "transition" (Transition), are generally from non-market economy to the market economy, are in private ownership within the socio-economic system. China's "transformation" or "transition" is from the socialist planned economy to socialist market economy, public ownership and market economy. Attention to the law of value, but do not think the law of value in itself all the things we will be able to manage well, and everything to the market to control. If some resources are limited, and the waste generated, then the resources will be depleted. In a free market economy, and there is no mechanism to ensure that limited resources have been the most proper use. Market economy is the root of the decision-making based on the consumer market trading prices of the products provided by the intelligence. Market regulation mechanism of defects and failures, government intervention in economic activities so that a space, is precisely because of this, the Government's macroeconomic regulation and control, the modern market economy has become an integral part of the system. As well-known economist and Nobel Economics Prize winner Paul Samuelson said, "today nothing can replace the market to organize a complex 
large-scale economy. The question is, the market had no heart, no mind, it does not Conscience, not thinking, no scruples. So. By the Government to formulate policies to correct some of the market by the economic shortcomings. " Therefore, the "modern market economy and government revenue, expenditure and regulation only visible hand of the mix." • Milton Friedman and many other individual economists believe that excessive government intervention and control will result in the transfer market intelligence obstruct or even stop was due to the normal operation of the market, he considered that this will cause many serious Government external issues such as inflation, recession and depression. - Milton Friedman that the Great Depression is in fact manufactured by the Government of the external triggered by. And the socialist market economy is adhering to market-oriented reforms, the Government must have effective regulation and intervention in the market to correct the deficiencies, there is a need to be coordinated plan guidance. Market economic system under the premise of "regulating plan" include: strategic guidance of the plan, the necessary government on economic management and control, and so on. Ensure that the balance of total economic output - the total demand, the supply of control: the restructuring of major issues, including the first, second and tertiary industries, consumption and accumulation, the processing industry and basic industries, and so on. Fair competition. Ecological balance, environmental protection and "not external economic" problem. Yixiang subjective and practical applications from. Sensitivity of the information poor, the failure will cause interference.

\section{Market imperfections and the role of the government's public policy focus}

Market failure, government failure and government intervention in the modern market economy, market regulation and government intervention, freedom of competition and macro-control, is closely linked, are intertwined, one can not do an important part. The market mechanism only in the complete validity of the hypothesis that strict conditions under which the establishment, and government intervention is also perfect with the only "good government" link. In other words, market regulation and government intervention is not a panacea, have inherent shortcomings and failures, the failure of the objective may be, the key is to seek economic and social development of the market mechanism with the best combination of government regulation and control, making government intervention in the remedy And correct market failures of the meeting, avoid and overcome the failures. There are shortcomings in the market, market failure is the root cause of information, the Government's focus on encouraging the production of information and ease the information asymmetry. Information of the most important faced by the system is bound by the special nature of the IT industry caused by the failure of the market system, the traditional market and non-market system is not inherent to the development of the IT industry. The need to carry out important non-market system innovation on the other hand, to promote market competition, the market system to play the basic role remains crucial. Non-market system of innovation and market system is complementary and not entirely replace the functions of the latter. To overcome constraints in the system, the Government is the most important non-market one of the innovation system, the Government must play in coordinating and providing public goods such as the active role.

Government intervention and the free market instead of two unrelated economic conditioning systems. Government intervention in economic activities is bound to play a role of the free market have a profound impact. Chinese are moving in the building of the socialist market economy path, the first time in history a socialist public ownership and market economy "with." Through the reform of enterprises, the state-owned enterprises into independent producers and operators, in public ownership economy as a market economy it must shape the microscopic foundation. Other areas of reform (such as fiscal, monetary, price, social security, etc.) must be compatible with it or services. In a market economy, the role played by the Government to the main types of social provision of public information services, to provide the public with information services, eliminating information asymmetries. In addition to the widespread problem of asymmetric information, positive information in the process of eliminating the digital divide. Actively provide government information, while also providing accurate and adequate product information, sufficient information and the real deal. To supply information to the public and specific requirements, the use of information superiority punishment unfair, unfair trade practices or administrative acts.

\section{References}

Cha, Xianjin, Yan Yalan. (2001). On the information market failure and government intervention. Chinese Library Journal. 04.

Tanchong, Taiwan. (2000). Development of the new development economics. Wuhan University Press in March, 2nd edition.

Wu, Jiapei. (2001). Information Society and the Communist Party's mandate, [Online] Available: http://www.candle.net.cn/kdwengao/2001/3/untitled25.htm.

Zhang, Jiwen, and so on (2002). Principle of e-commerce. Beijing: Electronics Industry Publishing House. 